\title{
Educommunication in digital environments: an interaction's perspective inside and beyond the classroom
}

\author{
La educomunicación en entornos digitales: una perspectiva de la \\ interacción dentro y más allá de las aulas de clase
}

RECIBIDO 11/6/2019 ACEPTADO 19/1/2020 PUBLICADO 1/6/2020

\author{
(iD) Andrés Chiappe \\ Centro de Tecnologías para la Academia, Universidad de La Sabana, Colombia \\ andres.chiappe@unisabana.edu.co \\ (iD) Nubia Amado \\ Maestría en Informática Educativa, Universidad de La Sabana, Colombia \\ nubiaamma@unisabana.edu.co \\ Leonardo Leguizamón \\ Maestría en Informática Educativa, Universidad de La Sabana, Colombia \\ leonardoleno@unisabana.edu.co
}

\section{ABSTRACT}

In a highly interconnected and technology-mediated world, how education is recognized as a communicative phenomenon is highly relevant to understand its development and future possibilities. In this text, educommunication is analyzed from the point of view of interactions that occur in different digital learning environments, especially in ICT-enhanced classrooms, blended learning, e-learning, mobile learning and massive open online courses (MOOC). This analysis was conducted from a systematic literature review of 240 papers that describe research generated on these topics, during the last 20 years.

The results show that beyond the importance of interaction for the development of educational practices, different digital environments involve different ways of conceiving and deploying interaction processes, inside and outside the classroom.

This implies the imperative need to adjust the current processes of teacher training in such a way that teachers can understand these differences and recognize both their theoretical and practical implications.

KEYWORDS computer-assisted learning, open education, interaction, information and communication technologies, learning environment.

\section{RESUMEN}

En un mundo altamente interconectado y mediado por tecnologías, la forma como la educación se reconoce como un fenómeno comunicativo resulta de alta relevancia para comprender su desarrollo y posibilidades futuras. En este texto, se analiza la educomunicación desde las interacciones que suceden en distintos entornos digitales de aprendizaje, especialmente desde la presencialidad apoyada en tecnologías de la información y la comunicación (TIC), el blended learning, e-learning, 
el aprendizaje móvil y los cursos masivos abiertos y en línea (MOOC). Este análisis se condujo a partir de una revisión sistemática de literatura de 240 artículos sobre la investigación generada sobre estos tópicos, durante los últimos 20 años.

Los resultados muestran que más allá de la evidente importancia que tiene la interacción para el desarrollo de las prácticas educativas, los distintos entornos digitales suponen distintas maneras de concebir y desplegar los procesos de interacción, dentro y fuera de las aulas de clase.

Lo anterior supone la necesidad imperiosa de ajustar los actuales procesos de formación docente de tal manera que lo profesores logren comprender estas diferencias y reconozcan sus implicaciones tanto teóricas como prácticas.

PALABRAS CLAVE aprendizaje asistido por ordenador, educación abierta, interacción, tecnologías de la información y la comunicación, ambiente de aprendizaje.

\section{INTRODUCTION}

Taking into account Tovar's (2013) approach, educommunication can be understood as the relationship between communication and education, a view that recognizes education as a communicative phenomenon.

When we look at 21st century classrooms and compare them with those of the previous two centuries, the differences should be obvious (Tafazoli et al., 2019). However, there are so many similarities in a classroom setup, rows distribution, the arrangement of students one after another, the use of materials, the ways of teaching, among others. This leads us to ask ourselves what has really changed inside the classroom in all those years? Has interaction changed and how? What would be the role of information and communication technologies inside these changes?

Defining communication for Fernández (2013), it implies the usage of three linked analysis units known as: the "communicative situation", the "communicative event" and the "communicative act", in an analogous way to the definitions of "activity", "action" and " operation ". Thus, a communicative situation would be a primary education class; a communicative event would be to resolve an exercise in class while a communicative act would be a turn of speech in interaction in a given communicative event.

Therefore, communication is a key factor in the learning process, which implies situations, events and acts of communication in the educational process where communication is an act of knowledge sharing with others (Aparici Marino, 2005).

Gunga and Ricketts (2008) state that education can, therefore, be defined as the range of activities and processes that lead to successful enculturation. It is the process of cultural transmission and renewal during which senior members of society guide the development of the younger generation by initiating them into the culture of the society. However, in current practice, education is not a linear process of information passing from the older to the younger people but one of the interactions that create new systems appropriate to current circumstances. Therefore, both adults and children participate in education to enhance their knowledge and skill levels.

Depicting education this way, it is crucial to reflect on the importance of interaction that creates new systems suitable to the current circumstances of communication between adults, children, knowledge, tools, needs and possibilities (Álvaro-Tordesillas et al., 2019).

Therefore, barriers of the past for communication in and out of the classroom, with the implementation of ICT tend to disappear in a new system of interrelations that knows no barriers in time, or space (Julio Cabero Almenara et al., 2010). 
Regarding this and according to Cánepa and Ardevol (2014) digital media (as a structural component for digital learning environments) is seen as a tool that transforms the relationships between teachers and students, in terms of temporalities for teaching and learning. Thus, it becomes vital at this point to be aware of the need to do deeper research about the importance of interaction as a key element of educommunication in digital environments in order to a better understanding of its issues.

\section{METHOD}

To address the mentioned above, a systematic literature review process was conducted following the recommendations of Gregory and Dennisse (2018) through the following phases:

1. Define topic and audience, in which the purpose of the review was defined and a guiding question was established: what are the similarities and differences in the interaction in different digital learning environments?

2. Searching the literature, in which the search descriptors were defined combining five different digital learning environments: "ICT-enhanced face-to-face classroom" OR "blended learning" OR "e-learning" OR "m-learning" OR MOOC AND "interaction "in both Scopus and Scielo, to include literature in English and Spanish, from high impact indexed journals. As a result, a first set consisting of 16.533 documents filtered by articles with research results in social sciences was configured.

3. Filtering and abstracting, in which verification was made through the reading of abstracts of the correspondence of the interaction approach as a central element of the pre-selected studies. From this process the set of documents was reduced to 420, of which 240 were selected for in-depth reading.

4. Data extraction and analysis, in which segments of text were extracted from the articles and key ideas related to the guiding question were identified, which were grouped by frequency of appearance and by thematic similarity.

\section{RESULTS}

\subsection{Interaction in and beyond ICT-enhanced face-to-face classroom}

Quesada and Solernou (2013) states that there are additional aspects to be taken into account during implementing educational communication such as the proper use of language (opportunity and adequacy, rhythm, cadence that makes it understandable), know how to speak and listen to others, encourage discussion in every single class, approaching to the interlocutor, be able to get in someone else's shoes, praise participation, respect and accept others as they are and as they think, look for educational solutions to conflicts, establish a favorable psychological learning environment, besides favoring and organizing team work.

On the surface, rows arrangement does not facilitate the possible interactions for exchanging, taking part, respecting and accepting the other. Perhaps, it is not an important element when communicating virtually.

Today it is a challenge for teachers to generate spaces for proper use of language, listening skills, an adequate communicative environment in new spaces of digital connection. Examples of studies addressing these issues are in Riley et al. (2017), Lorenzo (2017) or Zou and Thomas (2018). 
Another aspect to keep in mind when reflecting on interactions inside and outside the classroom in the face-to-face educational processes supported by ICT and communication technologies is the one that has to do with emerging or almost non-existent interaction beyond the classroom and the tendency to be teachercentered with traditional classes that go just one-way.

According to Hanzu and Barsan (2010), in the traditional way to teach, the bridge that works as a connection between teacher and student has been represented by facing one another and the direct knowledge exchange.

The description of how the new ways of teaching should not be addressed is presented in Chiappe and Arias (2016) which state that it is important to avoid reproducing beliefs and values that consolidate a patriarchal environment. In that sense, learning based on the dynamics of interaction between equals produces or stimulates actual learning.

As discussed above, current interactions inside and outside the classroom are highly mediated by social networks and the daily use of digital media, which has enabled the emergence of external and complementary communicative processes to those generated within classrooms.

Examples of studies addressing these issues are in Lobel et al. (2005) and Stanton and Stanton (2017).

\subsection{Interaction in and beyond blended learning}

According to Bartolomé (2004), the simplest and also the most precise definition of blended learning describes it as that way of learning that combines face-to-face teaching with non-face-to-face technology.

Morán (2012), define b-learning as combine face-to-face learning and distance learning in such a way that the best strategies of each modality are integrated and complemented to provide more flexible and solid learning experiences.

From this point of view, it is possible to establish a clear differentiation between blended learning and the ICT-enhanced classroom. The latter is seen as a pedagogical-technological proposal based on an almost face-to-face course in which several technological support is used to extend the teaching activity within the training proposal, beyond the traditional means of the classroom itself.

For blended learning, what matters is to combine face-to-face teaching with non-face-to-face technology. This distance education generates more flexible learning and interaction that goes beyond a classroom that is not included in the first one in the one hundred per cent face-to-face mode.

There are several examples of studies of this matter like Mariño (2006) and Salas and Pirela (2010) where state that there are many advantages and benefits offered by information and communication technologies (ICT) as means for combining face-to face with distance education.

In terms of interaction both inside and outside the classroom, there is also the already mentioned alternating physical separation between teacher and student.

An interesting aspect to mention is that this type of training experience allows teachers to use ICTs and to generate spaces for reflection on how and why they can significantly support training processes, understanding that it is not simply a matter of changing one tool for another so that the student feels more motivated, but that it is a fundamental issue implicit that involves re-thinking the teaching processes and the construction of knowledge from new perspectives. 
In this respect, Shu and Gu (2018) affirm that b-learning combines face-to-face learning and distance learning in such a way that the best strategies of each modality are harmoniously integrated and complemented, to provide more flexible and solid learning experiences.

Computer-mediated communication can be categorized as either synchronous or asynchronous interactions that occur by using different processes. Online synchronous interactions are sometimes considered as closely replicating face-to-face meetings, but participants are in different physical locations bridged using some sort of technological interface. Watson and Sutton (2012) states that blended learning is not a new concept. For years we have been combining face-to-face classes with exercises, case studies, role-plays and video and audio recordings, not to mention advice and tutoring. It is important that we keep in mind a concept for b-learning, or blended-learning: the term blended implies to mix. This mixture is face-to-face and distance training, in the latter using the Internet.

Regarding this issue, it states that virtual social networks allow the generation of new synergies among members of an educational community, facilitate the flowing of information, resources sharing, and above all, the projection and consolidation of interpersonal relationships once the courses come to an end.

In conclusion, it refers to the work done in both the classroom and on-line to achieve an effective learning outcome. The fundamental aspects in a b-learning training process would be defined in three great moments: initial face-to-face session, development through the network and virtual face-to-face session.

From this point of view, it is possible to establish a clear difference between blended learning and the ICT-supported classroom. The latter is seen as a pedagogical-technological proposal based on a practically face-to-face course and in which several technological supports are used to extend the teaching activity within the training proposal, beyond the traditional means of the classroom itself.

Examples of studies addressing these issues are in Shu et al. (2017), Castro and Lara (2017) and Perez et al. (2016).

\subsection{Interaction in e-learning environments}

According to Figueira (2009) e-learning has different names but refers to the same: training through the use of new technologies.

For Hijón-Nerira et al. (2008) e-learning is defined as non-face-to-face training with technological platforms, which enable and make flexible access and timing in the teaching-learning process, taking into account skills, needs and times of each student through the use of synchronous and asynchronous communication tools.

Diallo et al. (2014) state that e-learning is an online construct that can be updated, stored, retrieved and distributed so that it allows sharing instructions or data. Under this parameter, communication happens outside the classroom in a context that requires the use of technological tools in an asynchronous or synchronously; thus, the physical layout becomes non-existent as the space-time barriers disappear. All kinds of interaction are given outside the classroom with the use of virtual networks, which allows constant communication between participants, where all are participants and the role of the teacher is the one of a tutor.

In this context, communication and learning must be reformulated to interpret new spaces inside digital networks. Besides organizing and reviewing the technical processes, teachers will have new challenges to face in addressing the new quests of communicative processes, willing to get to a technological dialogue 
inside and outside the classroom where all participants share knowledge with their close classmates and with others anywhere in their country or all around the world (Jeffrey \& Craft, 2004).

Thus, in e-learning all kinds of interactions occur inside digital environments but not always inside virtual classrooms (LMS platforms). The use of digital networks allows constant communication between participants, where tutoring becomes a highly important component of interaction and of course, of learning.

Examples of studies addressing these issues are in Molinillo et al. (2018), Wise and Cui (2018) or Yengin et al. (2011).

\subsection{Interaction in m-learning environments}

Interaction within and beyond the classroom in m-learning, takes a new meaning, because of ubiquity, which involves the development of highly flexible online relationships where time restrictions disappear.

The interactions that occur in the m-learning mode are linked to how mobile devices are used and to the interaction or communicative interactivity, whether it would be the first, person to person and the second, person-technology.

It is important to emphasize that it is possible to make use of mobile devices in three different ways, in which interactions change but each of them allows a different type of learning.

In the first form, the main objective is to make use of the devices as content distribution channels. Through different elements such as podcasts, explanatory videos, among others prepared by the teacher, the student will have access to the content directly with the knowledge through devices. Examples of studies addressing these issues are in Wand and Shen (2012) or Ersoy-Babula and Babula (2018).

The second way is to use the mobile phone to create content outside the classroom, to learn in context, using the devices to collect different types of information in order to create new material, so the interaction will happen along with the use of mobiles to create content. Examples of studies addressing these issues are in Kazi (2007) or Troussas et al. (2017).

The third way is to use the mobile phone as an instrument of coupling and mediation in class, mobility in a classroom framework that allows the usage of different applications. For example, a Kahoot session allows us to generate different kinds of interaction with technology, with environments of competition, pauses, games, augmented reality, or QR codes. Besides, this manages to enrich the contents. Thus, depending on how you use it, the interaction will be different time after time.

Examples of studies addressing these issues are in Gholizadeh et al. (2018) or Li et al. (2018).

\subsection{Interaction within MOOCs}

Knowing as massive open online courses, this digital learning environment is conceptualized by Almenara et al. (2014) as:

an educational resource that has a certain similarity with a class, with a classroom, with start and end dates, with evaluation mechanisms, online, free and open use through the web, which does not have admission criteria and allows the large-scale interactive participation of hundreds of students. (p. 15) 
Advocates of MOOCs say that this type of courses come to revolutionize education as one of the social sectors that has not increased its productivity since its inception.

The scope of the MOOC phenomenon has immediately crossed frontiers, becoming an unsuspected quantity in higher education and professional training. However, other studies (Hone \& El Said, 2016) affirm that many are the arguments for and against this type of online course. Although they allow numerous students to be managed through the implementation of ICTs and thus improve productivity, we also find critical voices against MOOCs, mainly because of high dropout rates and above all, for the difficulties for providing proper and timely feedback for learning.

As a sign of contradiction, the interaction outside and inside the classroom in MOOCs, expands its possibilities because of the massiveness, so they are accessible to a greater number of people with diverse backgrounds, interests and learning expectations (Alraimi et al., 2015).

For education, the MOOC especially connects and communicates outside the classroom to all actors in the learning process, so learners in a MOOC are in potential connection with their classmates with a classroom called "the internet".

In conclusion, according to the above approach, it is not in the ICT or their specific characteristics, but in the activities provided in the MOOC, which makes possible the type of communication, the exchange and the access to information and knowledge.

Examples of studies addressing these issues are in Sunar et al. (2017), de Waard el al. (2012) or Velásquez-Sortino (2017).

As a synthesis, results show that depending on the type of MOOC in which the student is linked, the type of interaction generated will be different.

One of the great differences between MOOCs and other digital learning environments previously addressed, has to do with the fact that interactions exceed the limits of the people who traditionally make up a class group. In that order of ideas, a cMOOC (connectivist MOOC) enables collaboration, as a kind of interaction typical of digital environments, to go beyond a working relationship with my classmates and become an interaction "with the world" (Fidalgo-Blanco et al., 2016; Smith \& Eng, 2013).

In a very contrary way, the $\mathrm{xMOOC}$ (extended $\mathrm{MOOC}$ ) typically limits the student's interactions to a solo review of online video content and the completion of a test, and in a few cases, to a collateral participation in a discussion forum (Margaryan et al., 2015; Mohamed \& Hammond, 2018).

\section{DISCUSSION AND CONCLUSIONS}

In the context of educommunication, each addressed digital environments of learning, such as face-to-face ICT-enhanced classroom, e-learning, b-learning, m-learning and MOOC is considered complex and quite unique (Montepare, 2014). It would not be a novelty to conclude that in each one of them the usage of technology would be different and can also be differentiated both in related theory and practice.

As a result of the analysis of the extracted data it is possible to consider that all the digital learning environments analyzed allow in different ways the exchange of knowledge, and the possibility of creating new or varied learning from and with the use of several digital tools. The possibilities of sharing information allow students to appropriate knowledge, to recreate it, to change it, without limits of time and spaces (Géczy, 2009). 
Also, all of those environments have their codes that give relevance to a communicative aspect, be it oral, written, visual, or auditory, and changes due to the technological implementation, which require appropriate changes in teacher training both in these new codes handling and in the usage of ICT-based tools.

Regarding the above, it is noteworthy that there are some relevant differences in terms of the use of time. It is no longer necessary to be interacting at the same time in the classroom to achieve learning. New interactions are possible outside the classroom with the use of mobile tool, social media or web 2.0 services. Although face-to-face and b-learning need synchronicity of time to achieve learning goals, in other learning environments like e-learning or MOOC the apprentices should manage their time in a flexible way, according to their possibilities and needs.

In addition, the use of space for interaction is also different. Excluding ICT-enhanced face-to-face classrooms and blended learning, space barriers are gone, and interaction occurs anywhere in the world. Also, depending on the roles assumed by educational stakeholders, interaction differs. In this matter, MOOC is quite different from other digital learning environments. Thus, being interaction between teacher and student a critical factor for feedback and assurance of learning, in the MOOC, this does not apply. Even if interaction is important for learning in the MOOC, it does not happen due to the interaction with teachers, which is quite impossible because of the massiveness of the MOOC. However, feedback does not disappear, but it is generated by other students (from peer learning) or by other people involved in open activities or open spaces (open interaction).

Specifically, for m-learning, the interactions that occur in this environment are linked to how mobile devices are used. It is important to emphasize that it is possible to make use of mobile devices in three different ways.

In the first form, the main objective is to make use of the devices as content distribution channels. Through different elements such as podcasts, explanatory videos, among others prepared by the teacher, the student will have access to the content with the knowledge through devices.

The second way is to use the mobile device to create content outside the classroom, to learn in context, using the devices to collect different information to create new material, so the interaction will happen along with the use of mobiles devices to create content in situated learning experiences.

The third way is to use the mobile device as an instrument for enhancing interaction and engagement in face-to-face classroom mainly by using apps, QR codes and augmented reality.

New implications for interactions within and outside the classroom would be expected for the 21 st century education. It is key to understand the importance of the interaction that is created with the new digital systems which create new circumstances of communication between apprentices, knowledge, tools, needs and possibilities for an everchanging world.

\section{REFERENCES}

Almenara, J.C., Del Carmen Llorente Cejudo, M., \& Martínez, A. I. V. (2014). MOOC's typologies: Design and educational implications [Las tipologías de mooc: Su diseño e implicaciones educativas]. Profesorado, 18(1), 13-26.
Almenara, Julio Cabero, Osuna, J. B., \& Cejudo, M. del C. L. (2010). El diseño de Entornos Personales de Aprendizaje y la formación de profesores en TIC. Digital Education Review, 18, 3. 
Alraimi, K. M., Zo, H., \& Ciganek, A. P. (2015). Understanding the MOOCs continuance: The role of openness and reputation. Computers \& Education, 80, 28-38. https://doi.org/10.1016/j. compedu.2014.08.006

Álvaro-Tordesillas, A., Alonso-Rodríguez, M., Poza-Casado, I., \& Galván-Desvaux, N. (2019). Gamification experience in the subject of descriptive geometry for architecture. Educación XX1, 23(1). https://doi.org/10.5944/educxx1.23591

Aparici Marino, R. (2005). Medios de comunicación y educación. Revista de Educación, 338, 85-99.

Bartolomé, A. (2004). Blended learning. Conceptos básicos. PíxelBit. Revista de Medios y Educación, 23, 7-20.

Cánepa, G., \& Ardèvol, E. (2014). Diversidad cultural, visualidades y tecnologías digitales. Anthropologica Del Departamento de Ciencias Sociales, 32(33), 5-9.

Castro-Rodríguez, Y., \& Lara-Verástegui, R. (2017). Percepción del blended learning en el proceso enseñanza aprendizaje por estudiantes del posgrado de Odontología. Educación Médica, 1-6. https://doi.org/10.1016/j.edumed.2017.03.028

Chiappe, A., \& Arias, V. (2016). La Educomunicación en entornos digitales: Un análisis desde los intercambios de información. Opción, 32(7), 461-479.

de Waard, I., Koutropoulos, A., Hogue, R. J., Abajian, S. C., Keskin, N. Ö., Rodriguez, C. O., \& Gallagher, M. S. (2012). Merging MOOC and mLearning for Increased Learner Interactions: International Journal of Mobile and Blended Learning, 4(4), 34-46. https://doi.org/10.4018/jmbl.2012100103

Ersoy-Babula, A. I., \& Babula, M. (2018). Learning on the move business students' adaptation of virtual learning environment and mobile device technology. The International Journal of Management Education, 16(2), 321-326. https://doi. org/10.1016/j.ijme.2018.04.007

Fernández-Cárdenas, J. M. (2013). El habla en interacción y la calidad educativa: Los retos de la construcción de conocimiento disciplinar en ambientes mediados por tecnología digital. Revista Mexicana de Investigación Educativa, 18(56), 223-248.

Fidalgo-Blanco, Á., Sein-Echaluce, M. L., \& García-Peñalvo, F. J. (2016). From massive access to cooperation: Lessons learned and proven results of a hybrid $\mathrm{xMOOC/CMOOC}$ pedagogical approach to MOOCs. International Journal of Educational Technology in Higher Education, 13(1). https://doi.org/10.1186/ s41239-016-0024-z

Figueira, A. (2009). Mapping e-learning interactions using social network analysis. Proceedings of the 8th IASTED International Conference on Web-Based Education, WBE 2009, 66-72. https://www.scopus.com/inward/record.uri?eid=2-s2.074549205229\&partnerID=40\&md5=a6e2ef6e $77021613 \mathrm{be} 279$ $385 \mathrm{a} 9557 \mathrm{~d} 8 \mathrm{e}$

Géczy, P. (2009). Human behavior and interactions in web environments. ICEIS 2009 - 11th International Conference on Enterprise Information Systems, Proceedings, DISI, IS-5-IS-6. https://www.scopus.com/inward/record.uri?eid=2-s2.074549191075\&partnerID=40\&md5=491b2ce9a3239d630bbf9 ede $7220 c 60 b$

Gholizadeh, M., Taghiyareh, F., \& Alvandkoohi, S. (2018). Toward a Propensity-Oriented Player Typology in Educational Mobile Games: International Journal of Game-Based Learning, 8(2), 55-67. https://doi.org/10.4018/IJGBL.2018040105

Gregory, A. T., \& Denniss, A. R. (2018). An Introduction to Writing Narrative and Systematic Reviews-Tasks, Tips and Traps for Aspiring Authors. Heart, Lung and Circulation, 27(7), 893-898. https://doi.org/10.1016/j.hlc.2018.03.027

Gunga, S. O., \& Ricketts, I. W. (2008). The Prospects for E-Learning Revolution in Education: A philosophical analysis. Educational Philosophy and Theory, 40(2), 294-314. https://doi. $\operatorname{org} / 10.1111 / \mathrm{j} .1469-5812.2007 .00332 . x$

Hanzu-Pazara, R., \& Barsan, E. (2010). Teaching techniques-Modern bridges between lecturers and students. International Conference on Engineering Education and International Conference on Education and Educational Technologies - Proceedings, 176-181. https://www.scopus.com/inward/record. uri?eid=2-s2.0-79958747098\&partnerID=40\&md5=aaa78230 $1541043 a c 573 c 256 c 8384845$

Hijón-Neira, R., Velázquez-Iturbide, J. Á., Barn, B., \& Oussena, S. (2008). A Comparative Study on the Analysis of Students Interactions in e-Learning. 20-22. https://doi.org/10.1109/ ICALT.2008.282 
Hone, K. S., \& El Said, G. R. (2016). Exploring the factors affecting MOOC retention: A survey study. Computers \& Education, 98, 157-168. https://doi.org/10.1016/j.compedu.2016.03.016

Jeffrey, B., \& Craft, A. (2004). Teaching creatively and teaching for creativity: Distinctions and relationships. Educational Studies, 30(1), 77-87. https://doi. org/10.1080/0305569032000159750

Kazi, S. A. (2007). MILE: Mobile intelligent learning environment-A conceptual framework for mLearning. International Journal of Engineering Education, 23(3), 468-473.

Li, K. C., Lee, L. Y.-K., Wong, S.-L., Yau, I. S.-Y., \& Wong, B. T.-M. (2018). Effects of mobile apps for nursing students: Learning motivation, social interaction and study performance. Open Learning: The Journal of Open, Distance and e-Learning, 33(2), 99-114. https://doi.org/10.1080/02680513.2018.1454832

Lobel, M., Neubauer, M., \& Swedburg, R. (2005). Comparing How Students Collaborate to Learn About the Self and Relationships in a Real-Time Non-Turn-Taking Online and Turn-Taking Face-to-Face Environment. Journal of Computer-Mediated Communication, 10(4), 00-00. https://doi. org/10.1111/j.1083-6101.2005.tb00281.x

Lorenzo, A. R. (2017). Comparative study on the performance of bachelor of secondary education (BSE) students in educational technology using blended learning strategy and traditional face-to-face instruction. Turkish Online Journal of Educational Technology, 16(3), 36-46.

Margaryan, A., Bianco, M., \& Littlejohn, A. (2015). Instructional quality of Massive Open Online Courses (MOOCs). Computers \& Education, 80, 77-83. https://doi.org/10.1016/j.compedu.2014.08.005

Mariño, J. C. G. (2006). B-Learning utilizando software libre, una alternativa viable en Educación Superior. Revista Complutense de Educación, 17(1), 121.

Mohamed, M. H., \& Hammond, M. (2018). MOOCs: A differentiation by pedagogy, content and assessment. International Journal of Information and Learning Technology, 35(1), 2-11. https://doi.org/10.1108/IJILT-07-2017-0062

Molinillo, S., Aguilar-Illescas, R., Anaya-Sánchez, R., \& VallespínArán, M. (2018). Exploring the impacts of interactions, social presence and emotional engagement on active collaborati- ve learning in a social web-based environment. Computers \& Education, 123, 41-52. https://doi.org/10.1016/j.compedu.2018.04.012

Montepare, J. M. (2014). Nonverbal Behavior in the Digital Age: Meanings, Models, and Methods. Journal of Nonverbal Behavior, 38(3), 279-281. https://doi.org/10.1007/s10919-014$0187-z$

Morán, L. (2012). Blended-learning. Desafío y oportunidad para la educación actual. EDUTEC, Revista Electrónica de Tecnología Educativa, 39. http://edutec.rediris.es/Revelec2/Revelec39/ pdf/Edutec-e_39_\%20Moran.pdf

Perez Pinal, F., Nava, S., Nunez Perez, J., Araujo Vargas, I., Vera Cardenas, E., \& Barranco Gutierrez, A. (2016). Experimental Blearning laboratory for an electrical machines undergraduate course. IEEE Latin America Transactions, 14(2), 524-529. https://doi.org/10.1109/TLA.2016.7437188

Quesada, M., \& Solernou, I. A. (2013). Acercamiento al estudio de la comunicación educativa en una facultad universitaria en salud. Educación Médica Superior, 27(4), 366-373.

Riley, J. M., Ellegood, W. A., Solomon, S., \& Baker, J. (2017). How mode of delivery affects comprehension of an operations management simulation: Online vs face-to-face classrooms. Journal of International Education in Business, 10(2), 183-200. https://doi.org/10.1108/JIEB-09-2016-0025

Salas, A., \& Pírela, J. L. (2010). Diseño de una metodología de gestión del conocimiento para la educación a distancia sustentada en el enfoque B-Learning. 1 Jornadas Internacionales de Educación a Distancia, 1-6. http://sed.luz.edu. ve/jornadas/wp-content/uploads/Dise $\%$ C3\%83\%C2\%B1ode - una - M e todolog \% C $3 \% 83 \%$ C 2 \% A D a - d e Gesti\%C3\%83\%C2\%B3n_A_Salas.pdf

Shu, H., \& Gu, X. (2018). Determining the differences between online and face-to-face student-group interactions in a blended learning course. The Internet and Higher Education, 39, 13-21. https://doi.org/10.1016/j.iheduc.2018.05.003

Shu, H., Wei, Y., \& Gu, X.-Q. (2017). Is There Difference between In and Out of Classroom? Harnessing the Group Interaction of Blended Learning. 186-188. https://doi.org/10.1109/ ICALT.2017.159 
Smith, B., \& Eng, M. (2013). MOOCs: A Learning Journey. In S. K. S. Cheung, J. Fong, W. Fong, F. L. Wang, \& L. F. Kwok (Eds.), Hybrid Learning and Continuing Education (Vol. 8038, pp. 244-255). Springer Berlin Heidelberg. https://doi.org/10.1007/978-3642-39750-9_23

Stanton, W. W., \& Stanton, A. D. (2017). Traditional and Online Learning in Executive Education: How Both Will Survive and Thrive: Traditional and Online Learning in Executive Education. Decision Sciences Journal of Innovative Education, 15(1), 8-24. https://doi.org/10.1111/dsji.12119

Sunar, A. S., White, S., Abdullah, N. A., \& Davis, H. C. (2017). How Learners' Interactions Sustain Engagement: A MOOC Case Study. IEEE Transactions on Learning Technologies, 10(4), 475-487. https://doi.org/10.1109/TLT.2016.2633268

Tafazoli, D., Abril, C. A. H., \& Parra, M. E. G. (2019). Technologybased review on Computer-Assisted Language Learning: A chronological perspective. Píxel-Bit. Revista de Medios y Educación, 54, 29-44.

Tovar, N. (2013). La educomunicación en la universidad virtual: Retos del modelo/Educommunication in the Virtual University: Challenges of the model. Estudios Sobre El Mensaje Periodístico, 19, 491-499.

Troussas, C., Krouska, A., \& Virvou, M. (2017). Social interaction through a mobile instant messaging application using geographic location for blended collaborative learning. 1-5. https:// doi.org/10.1109/IISA.2017.8316395

Velázquez Sortino, M., Gómez-Zermeño, M. G., \& Alemán De La Garza, L. (2017). Interactions in a massive, online, open course (MOOC) for teacher's. Proposal for a model of analysis [Interacciones en un curso en línea, abierto y masivo para docentes. Propuesta para un modelo de análisis]. Digital Education Review, 31, 149-175.

Wang, M., \& Shen, R. (2012). Message design for mobile learning: Learning theories, human cognition and design principles: Message design for mobile learning. British Journal of Educational Technology, 43(4), 561-575. https://doi.org/10.1111/ j.1467-8535.2011.01214.x

Watson, S., \& Sutton, J. M. (2012). An examination of the effectiveness of case method teaching online: Does the technology matter? Journal of Management Education, 36(6), 802-821.
Wise, A. F., \& Cui, Y. (2018). Learning communities in the crowd: Characteristics of content related interactions and social relationships in MOOC discussion forums. Computers \& Education, 122, 221-242. https://doi.org/10.1016/j.compedu.2018.03.021

Yengin, I., Karahoca, A., \& Karahoca, D. (2011). E-learning success model for instructors' satisfactions in perspective of interaction and usability outcomes. Procedia Computer Science, 3, 1396-1403. https://doi.org/10.1016/j.procs.2011.01.021

Zou, B., \& Thomas, M. (Eds.). (2018). Handbook of Research on Integrating Technology Into Contemporary Language Learning and Teaching: IGI Global. https://doi.org/10.4018/978-15225-5140-9 